\title{
Impact of Education Program on Health Related Behaviors Among Patients With Chronic Viral Hepatitis C
}

\author{
Prof. Mamdouh Al-Mezaien Prof. Kawther Gaber, Dr. Amal Bakr Abo EL-Ata, \\ Amany Gamal
}

Department of general and vascular Surgery, Faculty of Medicine, Suez Canal University, Department of Medical Surgical Nursing, Faculty of Nursing, Alexandria University, Department of Medical Surgical Nursing, Faculty of Nursing, Port Said University Department of Medical Surgical Nursing, Faculty of Nursing, Port Said University.

\begin{abstract}
Background: Hepatitis $\mathrm{C}$ virus infection is the major etiological agent of chronic hepatitis and liver disease worldwide. It is estimated that approximately 130-210 million individuals of the world population are chronically infected with HCV .Egypt has the highest prevalence of HCV is worldwide, representing that $15 \%$ of the general population in Egypt have $\mathrm{HCV}$, responsible for almost $90 \%$ of infections that cause chronic liver disease and death in the country.Objectives: The aim of this study was to evaluate the effect of an educational program on health related behaviors among patients with chronic viral hepatitis $\mathrm{C}$ treated by pegylated alpha interferon and ribavirin combination therapy subject and methods :The research design was Quasi experimental. The sample constituted of 216 hepatic $C$ patients were classified into two equal groups: control and study, treated by alpha pegylated interferon and ribavirin combination therapy in El-Tadamon hospital in Port -Said city. The tool that is used for data collections was Hepatitis C Virus Health Related Behaviors Assessment Questionnaire. Results: revealed that There was a statistically significant difference between the study and the control group regarding total scores health behaviors before, and after three and six months of the program $(p=0.018,0.0001$, 0.0001).The conclusion: depicted that statistically significant improvement of CHC patients' health behaviors was found regarding HCV disease during the health education program phases. Based on this finding, the research hypothesis was fulfilled.

. Recommendation: The study recommended development of a health education unit in each specialized liver center with the availability of qualified and trained nurses. Nurses should hold sessions to provide health education and counseling for these patients.
\end{abstract}

Key words :Education program, Knowledge, Viral Hepatitis C. 


\section{INTRODUCTION}

Hepatitis $\mathrm{C}$ is a disease with a significant global impact. According to the World Health Organization there are about 130-210 million people chronically infected with the hepatitis $\mathrm{C}$ virus (HCV), corresponding to 2- $2.5 \%$ of the world's total population (CDC, 2015).

$\mathrm{HCV}$ can be a difficult disease to manage, lifestyle plays an integral part in HCV disease management and treatment; changing life style and personal behaviors reduce the effect of chronic HCV. Proper diet, exercise, rest, sleep, and stress management are all critical to maintain good health (McCoombs, 2010).

Hepatitis $\mathrm{C}$ is largely affected by human behaviors, particularly tobacco use, diet and activity pattern, alcohol consumption, sexual behaviors, and avoidable injuries. Thus behavior changes recommended to reduce disease progression include decreased alcohol consumption, decreased tobacco use, and vaccination against hepatitis $\mathrm{A}$ and $\mathrm{B}$, decreased drug use through injection, decreased sharing of injecting equipment, increased condom use, complete covering of all cuts and sores and decreased sharing of household or personal care items that might be contaminated with blood that is recommended to reduce the risk of disease transmission (June et al., 2011).

Therefore, there is a need to provide those patients with health education to cope with their disease and improve their health behaviors to enhance their quality of life and accordingly an educational program is designed .Such a program would provide a solid foundation for caring of such patients. It will help the nurse manage each patient's care scientifically, holistically, creatively based on patient's individual needs (Foster et al. , 2011).

Significance of the Study

Hepatitis $\mathrm{C}$ virus is a significant nursing problem because of the high prevalence of the population affected and the serious consequences of uncontrolled chronic hepatitis $\mathrm{C}$ (CHC). In Egypt, HCV infection rates are increasing at an alarming rate leading to a burden disease. Prevalence rates are ten to twenty folds higher than those reported in most countries worldwide. El-Berdan, (2013) revealed that $\mathrm{CHC}$ patients have poor health behaviors about their disease so, there was an important need to conduct this study to identify unhealthy behaviors to develop a health education program for them. 
This study will contribute in improving conditions of those patients, as well as helping in preventing and controlling infection to other people through health education.

\section{AIM OF STUDY:}

To evaluate the effect of an education program on health related behaviors among patients with chronic viral hepatitis $\mathrm{C}$ treated by pegylated alpha interferon and ribavirin combination therapy.

\section{Objectives:-}

1- Determining unhealthy behaviors among chronic hepatitis $C$ virus patients.

2- Designing an educational program based on detection of prioritized correction of unhealthy behaviors and problems.

3- Implementing an education program on health related behaviors among patients with chronic viral hepatitis $\mathrm{C}$.

4- Evaluating the effect of an education program on health related behaviors and health status of chronic hepatitis $\mathrm{C}$ virus patients

\section{Research Hypotheses}

H1: After completion of the education program, patient's knowledge scores about their disease would be higher than before implementation of the program.

$\mathrm{H} 2$ : Patients who receive the education program will have higher knowledge scores than those who don't.

\section{SUBJECT AND METHODS:}

\section{Research Design:}

A quasi experimental research design (non-equivalent group design.

\section{Subjects:}

The estimated sample size was 196 chronic hepatitis C (CHC) patients. After adjustment for a dropout rate of $10 \%$, the sample size was increased to 216 patients. Those patients were classified randomly into two equal groups: control and study each group 108 patients for each.

\section{Setting:}

The study was conducted in the interferon unit at El-Tadamon Hospital in Port Said city; it is a health insurance hospital that services all patients in Canals' cities, Damietta and Sinai. 


\section{Tool for data collection}

Hepatitis C Virus Health Related Behaviors Assessment Questionnaire: This tool was developed the researcher master thesis by El-Berdan, (2013) to assess the health behaviors among patients with HCV, It compromised three parts:

Part (II): Medical background data: This part included data related to the following areas:

\section{A- Past family history of patients.}

B- Past Medical History : Included onset, symptoms and duration of disease, presence of other chronic diseases, drug history, past hospitalization, prescribed treatment and history of surgeries, blood transfusion, previous dental procedures , antibilharzias (tartar) therapy, history of needle stick injuries and sharing infected equipment with $\mathrm{HCV}$.

C- Present Medical History: Included the present signs and symptoms related to HCV patient complaints and the adverse effects of interferon therapy.

Part (III): Included items related to patients' knowledge about hepatitis C: It was composed of 12 items addressed knowledge of patients enrolled in the study about hepatitis $\mathrm{C}$ virus infection. It was used to measure patients' knowledge in relation to the following items : definition, signs, symptoms, risk factors, mode of transmission, diagnostic procedures needed for HCV diagnosis, complications and treatment of CHC patients that included contraindication, follow up, duration of treatment and side effects of Pegylated alpha interferon and Ribavirin combination therapy. This part was used as pre/post test for the study and the control group.

Part (III): Hepatitis C Virus Health Related Behaviors Assessment Questionnaire This tool was designed by El- Berdan, (2013) to assess the health behaviors among patients with $\mathrm{HCV}$; it is included 52 items related to four health behaviors areas:

1- Physical Health Behaviors: included 43 questions related to rest and sleep nutritional habits, elimination habits ,daily activities \& physical exercise regimens, hygienic care habits ,health promotion habits ,sexual relationship and negative habits.

2- Psychological Health Behaviors: included three questions related to change in psychological status, causes for such changes related patient's opinion and actions done to improve the psychological conditions.

3- Social relations with family and/or friends health behaviors: included three questions related to change in social relationships, causes for such changes in social relations, related patient's opinion and actions done to improve social relations. 
4- Spiritual health behaviors: included three questions related to change in spiritual conditions, causes for such changes related patient's opinion and actions done to improve spiritual conditions.

\section{Scoring system of health behaviors:}

Patients' total health behavior score was calculated as following:

Two points were given for each response reported by the patient to indicate activity undertaken to maintain their health status, prevent complications and transmission of hepatitis $\mathrm{C}$ virus to others.

One point was given for each response reported by the patient to indicate activity undertaken by patients and has no effect to maintain their health status, prevent complications, and transmission of hepatitis $\mathrm{C}$ virus to others.

A zero point was given for each response reported by the patient who is against maintenance of their health status, prevent complications, and transmission of hepatitis $\mathrm{C}$ virus to others.

The total score was calculated as the following:

-More than $60 \%$ of the total health related behaviors scores were considered good

- From less than $60 \%$ to $30 \%$ of total health related behaviors scores were considered fair.

-From less than $30 \%$ to zero of total health related behaviors scores were considered poor.

\section{Methods of study:}

- An official permission was obtained from the directors of the interferon unite at Eltadamon Hospital in Port-Said city, through an official formal letters from the dean of The Faculty of Nursing Port Said University.

- Informed consent was obtained from each CHC patient in the study after explaining its purpose and importance. Confidentially of the information was assured by the researcher.

- A pilot study was carried out after the development of the tools. It was carried out on $10 \%$ of participants (22 patients with chronic hepatitis $\mathrm{C}$ virus) to test the reliability and applicability of the tools of the study. The necessary modification was done based on 
the results of the pilot study. Those CHC patients were excluded from the subjects of research.

- The actual study was conducted through four phases: assessment phase, program development phase, implementation phase and evaluation phase.

\section{I .Assessment phase:}

In this stage, the researcher assessed CHC patients' learning needs using patient's knowledge assessment part. The researcher distributed the sheet to each patient and asked them to complete it. The tool was filled in about 30 minutes to an hour. Also, Red Cross organization in Port-Said city assisted the researcher in organization the class of sessions, equipment and supplies as (Computer-data show, Posters, flannel board and camera).

\section{Educational program development phase}

The training program was developed based on the identified needs and demands of CHC patients gathered in phase $\mathbf{I}$. In the light of the most recent pertinent literature and based on El-Berdan master thesis (2013).This phase included the following;

A -Objectives:- Improving CHC patients' knowledge related to HCV disease

B- Contents: Covered all areas about hepatitis $\mathrm{C}$ virus infection which include: definition, signs \& symptoms, risk factors, mode of transmission, diagnostic procedures needed for $\mathrm{HCV}$ diagnosis, complications and treatment of $\mathrm{CHC}$ patients that included contraindication, follow up, duration of treatment and side effects of Pegylated alpha interferon and Ribavirin combination therapy.

C-Planning: In this step the researcher designed a plan for a training program implementation. This plan included visiting the interferon unit in El - Tadamon hospital in Port- Said city twice weekly (Saturday and Sunday) in the morning and afternoon shifts that applied the program in four sessions for one month that every session was repeated twice weekly, one on Saturday for females in the morning shift and on males in afternoon shift. Every session lasted for 30 to 45 minutes and the second session for non-educated CHC patients at Sunday where females in morning shift while males in afternoon shift and every session lasted for 45 to 90 minutes. 


\section{C- Clinical area preparation:}

A written permission was obtained from the director of El- Tadamen Hospital and the head of interferon unit in Port- Said city, to carry out the study after introducing the objectives and significance of the study aim.

CHC patients were informed to participate in the study according to their needs. The study was carried out only on patients who participated in all sessions of the education program.

Many copies of the questionnaire and the education program were prepared by the researcher to facilitate learning and evaluation $\mathrm{CHC}$ patients' knowledge related their disease.

\section{III-Program implementation:}

The study group was divided into four subgroups to achieve the best results through homogeneity regarding gender and level of education (27 patients each).

A copy of $\mathrm{HCV}$ illustrated booklet and film about knowledge of $\mathrm{HCV}$ infection on a copy - right disk CD was given to educated $\mathrm{CHC}$ patients while $\mathrm{HCV}$ illustrated brochures was given to uneducated $\mathrm{CHC}$ patients to facilitate remembering the knowledge .

The education program was given to patients of the study group only, in a clear and concise manner. The researcher used selected adult teaching methods as role playing and discussion, and teaching media as films, videos, data show and brochures. CHC patients had opportunity to discuss their own experience and the researcher was clarified any queries and explained the unknown issues.

\section{IV- Evaluation phase:}

To evaluate the effect of the program, pre/post test was given to both study and control groups, immediately after program implementation, three months and six months after program implementation.At the end of the program evaluation, the educational booklets, brochures and videos on copy- right disk $C D$ were given to the control group to provide the same educational opportunity for all subjects. To collect data in the above mentioned duration, this necessitated visiting the interferon unit in El - Tadamon hospital in PortSaid city twice weekly (Saturday and Sunday) in the morning and afternoon shifts twice weekly, one on Saturday for females in the morning shift and on males in afternoon shift. Every session lasted for 30 to 45 minutes and the second session for non-educated CHC patients at Sunday where females in morning shift while males in afternoon shift and every session lasted for 45 to 90 minutes. 


\section{Statistical analysis of data:}

Up completion of data collection, variables included in the structured interview sheet, were coded prior to computerizing data entry. The raw data were coded and transformed into coding sheets. The results were checked. Then, the data were entered using SPSS 20.0 statistical software package. Output drafts were checked against the revised coded data for typing and spelling mistakes. Finally, analysis and interpretation of data were conducted.

\section{RESULTS:}

Table (1): reveals a non significant difference between study and control groups. It is noticed that, slightly more than half of the study and the control groups are males $(55.6 \% \& 58.3 \%)$. In addition, the same table illustrates that, the age of patients under study ranges between $20-50$ years.

Regarding the level of education, it reveals that, an equal percentage (15.7\%) of the study and the control groups are illiterate, slightly more than one third of the study and the control groups can read and write $(39.8 \% \& 37.0 \%)$ respectively, while the minority of the study and the control groups have postgraduate $\left(\begin{array}{lll}0.9 & \& & 3.7\end{array}\right)$ respectively.

Concerning occupation, it is found that, majority of the patients in the study and the control groups are workers $(80.6 \% \& 77.8 \%)$ respectively, while, the rest of them are not working. As regards to marital status, the same table manifests that, $79.6 \%$ \& $48.1 \%$ of the study and the control groups are married. Regarding place of residence, it is found that, about two thirds of the study group and three quarters of the control group lived in urban areas $(63.9 \% \& 76.9 \%)$ respectively.

Regarding the number of family members at home, it is ranged between 1-15 members in both groups. It is noticed that, three quarters of the study group (75.9\%) have less than four members in the family compared to $96.3 \%$ in the control group. Moreover, family income, it is clear from table that, half of the study group and around three quarters of the control group haven't enough monthly income $(50.0 \%$ \&75.9) respectively.

Table (2): shows distribution of CHC patients (study and control groups) according to their medical history. It is noticed that, the most common method of detection of the disease is accidentally among both groups with equal percent (60.2\%), while the lowest percentage of them $(0.9 \%)$ discovered disease by the routine investigation. It is 
clear that, the most commonly reported symptoms in the study and the control groups are loss of appetite $(53.7 \% \& 63.0 \%)$, arthralgia $(64.3 \% \& 55.6 \%)$, fatigue $(44.4 \% \&$ $54.6 \%)$, weight loss (40.7\% \& 52.9\%), nausea and vomiting (34.3\% \& 42.6\%) and abdominal cramp $(25.0 \%$ \& $34.3 \%)$ respectively, while the lowest symptom reported by the study and the control groups was diarrhea $(4.6 \% \& 16.7 \%)$ respectively. Concerning the duration of $\mathrm{HCV}$ disease, it is observed that, $60.2 \% \& 48.1 \%$ have suffered from HCV since one - five years. Also, the table reveals that, all of patients in both groups have a history of previous hospitalization and are treated by pegylated alpha interferon and ribavirin combination therapy.

Table (3): illustrates distribution of $\mathrm{CHC}$ Patients (study and control groups) according to exposure to risk factors of HCV infection The most commonly observed risk factors in the study and the control groups are sharing personal tools may be infected with $\mathrm{HCV}$ patient's blood $86.1 \%$ \& $81.5 \%$, previous dental procedures $48.1 \%$ \& $46.3 \%$, and history of needle stick injuries $15.7 \%$ \& $25.9 \%$ respectively. It is noticed that, $25.0 \% \& 27.3 \%$ of the control group has a past history of blood transfusion and surgical procedures respectively.

Table (4): shows frequency distribution of the study and control groups according to total scores of health behaviors (physical, psychological, social, and spiritual. The results shows that, $71.3 \% \& 55.6 \%$ respectively of the study and the control group has poor physical health behaviors before program implementation, which are significantly improved immediately, after three and six months of program implementation in the study group, and compare to the control group $11.1 \%, 21.3 \%$, $\& 14.8 \%, \& 39.8 \%, 29.6 \%, \& 39.8 \%$ respectively with a statistically significance $p=0.005, \& 0.0001$. There is a highly statistically significant difference between the study and the control group regarding physical health behaviors immediately and after three months of the program $\mathrm{p}=0.0001$.

Regarding the total score of psychological health behaviors, the results shows that, $83.3 \% \& 39.8 \%$ respectively of the study and the control group have poor psychological health behaviors before program implementation, which are significantly improved immediately, after three and six months of program implementation in the study group, and the control group a17.6\%, 23.1\%, \&10.2\%a, \& a38\%, 39.8\%, \&38\% respectively with a statistically significance $\mathrm{p}=0.0001$. There is a highly statistically significant difference between the study and the control group regarding total scores of physical health behaviors immediately after the program $\mathrm{p}=$ 
0.0001. Concerning the total score of social health behaviors, the results illustrates that, $21.3 \%$ of patients have good social health behaviors before program implementation, which are significantly improved immediately, after three and six months of program implementation in the study group only $55.6 \%, 37.0 \%, \& 37.0 \%$, respectively with a statistically significance $p=0.005$. There is a statistically significant difference between the study and the control group regarding total scores of social health behaviors after three and six months of the program $\mathrm{p}=0.049$.

As regards to the total score of spiritual health behaviors, the results reveals that, $14.8 \%$, \& $5.6 \%$ of the study and the control groups have good spiritual health behaviors before program implementation, which are significantly improved immediately, after three and six months of program implementation in the study group only $71.3 \%, 63.9 \%$, \& $26.8 \%$, respectively with a highly statistically significance $p=$ 0.0001 . There is a statistically significant difference between the study and the control group regarding total scores of social health behaviors after three and six months of the program $\mathrm{p}=0.0001$.Finally, the same table clarifies that, $11.1 \%, \& 21.3 \%$ of the study and the control groups had good total health behaviors before program implementation, which are improved immediately, after three and six months of program implementation in the study group only $61.1 \%, 75.9 \%$, \& $14.8 \%$, respectively with a highly statistically significance $p=0.0001$. There is a statistically significant difference between the study and the control group regarding total scores health behaviors before, and after three and six months of the program $p=0.018$, $0.0001,0.0001$.

Table (5): shows Correlation between health behaviors related HCV and sociodemographic characteristics among the study and control groups. There is moderate positive correlation between female gender and the total health behaviors at $r=0.65, \&$ $\mathrm{p}=0.05$ ) compared to no correlation in the control group. In relation to age, there is negative correlation between the age and the total health behavior at $\mathrm{r}=0.88 \mathrm{p}=0.001$, while there is no correlation in the control group. As regards to the educational level, it was noticed a strong positive correlation between the educational level and the total health behavior in the study group at $r=0.75 \mathrm{p}=0.001$, while there is no correlation in the control group. Concerning the marital status, there is positive correlation between the marital status and the total health behaviors among married patients in the study group at $(\mathrm{r}=0.48 \mathrm{p}=0.005)$ compared to no correlation in the control group. There is negative correlation between patient's lived in rural areas in the study group and the 
total health behavior in the study group $r=-0.77, \& p=0.001$, but there is a negative correlation between patient's reside in rural areas and the total health behavior in the control group $\mathrm{r}=-0.48, \& \mathrm{p}=0.62$

Table (1): Socio-demographic characteristics of $\mathrm{CHC}$ patients in the study and control groups $(\mathrm{N}=216)$

\begin{tabular}{|c|c|c|c|c|c|}
\hline \multirow[t]{2}{*}{ Socio-demographic characteristics } & \multicolumn{2}{|c|}{$\begin{array}{c}\text { Study group } \\
(n=108)\end{array}$} & \multicolumn{2}{|c|}{$\begin{array}{c}\text { Control group } \\
(n=108)\end{array}$} & \multirow[t]{2}{*}{ Significance } \\
\hline & No. & $\%$ & No. & $\%$ & \\
\hline $\begin{array}{l}\text { Gender } \\
\text { Male } \\
\text { Female }\end{array}$ & $\begin{array}{l}60 \\
48 \\
\end{array}$ & $\begin{array}{l}55.6 \\
44.4\end{array}$ & $\begin{array}{l}63 \\
45 \\
\end{array}$ & $\begin{array}{l}58.3 \\
41.7\end{array}$ & $\begin{array}{l}X^{2}=0.62 \\
P=0.891\end{array}$ \\
\hline $\begin{array}{l}\text { Age } \\
20- \\
30- \\
40- \\
50-\end{array}$ & $\begin{array}{l}24 \\
40 \\
24 \\
20\end{array}$ & $\begin{array}{l}22.2 \\
37.0 \\
22.2 \\
18.5\end{array}$ & $\begin{array}{l}22 \\
45 \\
24 \\
17\end{array}$ & $\begin{array}{l}20.4 \\
41.7 \\
22.2 \\
15.7\end{array}$ & $\begin{array}{c}X^{2}=0.17 \\
P=0.68\end{array}$ \\
\hline $\begin{array}{l}\text { Educational level } \\
\text { Illiterate } \\
\text { Read and write } \\
\text { Basic education } \\
\text { Secondary education } \\
\text { Technical education } \\
\text { University education } \\
\text { Postgraduate studies }\end{array}$ & $\begin{array}{c}17 \\
43 \\
8 \\
34 \\
0 \\
5 \\
1 \\
\end{array}$ & $\begin{array}{c}15.7 \\
39.8 \\
7.5 \\
31.5 \\
0.0 \\
4.6 \\
0.9 \\
\end{array}$ & $\begin{array}{c}17 \\
40 \\
9 \\
19 \\
6 \\
13 \\
4 \\
\end{array}$ & $\begin{array}{c}15.7 \\
37.0 \\
8.3 \\
17.6 \\
5.6 \\
12.1 \\
3.7 \\
\end{array}$ & $\begin{array}{l}X^{2}=0.62 \\
P=0.891\end{array}$ \\
\hline $\begin{array}{l}\text { Occupation } \\
\text { Not working/housewife/retired } \\
\text { Employee } \\
\text { Free work }\end{array}$ & $\begin{array}{l}21 \\
30 \\
57 \\
\end{array}$ & $\begin{array}{l}19.4 \\
27.8 \\
52.8 \\
\end{array}$ & $\begin{array}{l}24 \\
22 \\
62 \\
\end{array}$ & $\begin{array}{l}22.2 \\
20.4 \\
57.4 \\
\end{array}$ & $\begin{array}{l}X^{2}=0.25 \\
P=0.615\end{array}$ \\
\hline $\begin{array}{l}\text { Marital status } \\
\text { Single } \\
\text { Married } \\
\text { Divorced/widow }\end{array}$ & $\begin{array}{c}7 \\
86 \\
15 \\
\end{array}$ & $\begin{array}{c}6.5 \\
79.6 \\
13.9 \\
\end{array}$ & $\begin{array}{c}49 \\
52 \\
7\end{array}$ & $\begin{array}{c}45.4 \\
48.1 \\
6.5 \\
\end{array}$ & $\begin{array}{l}X^{2}=1.24 \\
P=0.266\end{array}$ \\
\hline $\begin{array}{l}\text { Residence } \\
\text { Urban } \\
\text { Rural }\end{array}$ & $\begin{array}{l}69 \\
39 \\
\end{array}$ & $\begin{array}{l}63.9 \\
36.1 \\
\end{array}$ & $\begin{array}{l}83 \\
25 \\
\end{array}$ & $\begin{array}{l}76.9 \\
23.1 \\
\end{array}$ & $\begin{array}{l}X^{2}=0.25 \\
P=0.615\end{array}$ \\
\hline $\begin{array}{l}\text { Number of family members at } \\
\text { home } \\
1-5 \\
6-10 \\
11-15 \\
\end{array}$ & $\begin{array}{c}82 \\
25 \\
1 \\
\end{array}$ & $\begin{array}{c}75.9 \\
23.1 \\
0.9 \\
\end{array}$ & $\begin{array}{c}104 \\
0 \\
4 \\
\end{array}$ & $\begin{array}{c}96.3 \\
0.0 \\
3.7 \\
\end{array}$ & $\begin{array}{l}X^{2}=0.62 \\
P=0.891\end{array}$ \\
\hline $\begin{array}{l}\text { Family income } \\
\text { Insufficient } \\
\text { Sufficient } \\
\text { More than enough }\end{array}$ & $\begin{array}{c}54 \\
50 \\
4\end{array}$ & $\begin{array}{c}50.0 \\
46.3 \\
3.7\end{array}$ & $\begin{array}{c}82 \\
22 \\
4\end{array}$ & $\begin{array}{c}75.9 \\
20.4 \\
3.7\end{array}$ & $\begin{array}{l}X^{2}=0.62 \\
P=0.891\end{array}$ \\
\hline
\end{tabular}


Table (2): Distribution of $\mathrm{CHC}$ patients (study and control groups) according to their family and medical history $(\mathrm{N}=216)$

\begin{tabular}{|c|c|c|c|c|}
\hline \multirow[t]{2}{*}{ Family and medical history } & \multicolumn{2}{|c|}{$\begin{array}{l}\text { Study group } \\
\quad(n=108)\end{array}$} & \multicolumn{2}{|c|}{$\begin{array}{c}\text { Control group } \\
(n=108)\end{array}$} \\
\hline & No. & $\%$ & No. & $\%$ \\
\hline \multicolumn{5}{|l|}{ Family history } \\
\hline \multicolumn{5}{|l|}{ Family past history of $\mathrm{HCV}$} \\
\hline Yes & 57 & 52.8 & 58 & 53.7 \\
\hline No & 51 & 47.2 & 50 & 46.3 \\
\hline $\begin{array}{l}\text { \#Family member with HCV } \\
\text { [n=109] }\end{array}$ & {$[\mathrm{n}=57]$} & & {$[\mathrm{n}=58]$} & \\
\hline $1^{\text {st }}$ degree & 34 & 59.6 & 38 & 65.5 \\
\hline $2^{\text {nd }}$ degree & 15 & 26.3 & 10 & 17.2 \\
\hline $3^{\text {rd }}$ degree & 5 & 8.8 & 4 & 7.0 \\
\hline $4^{\text {th }}$ degree & 3 & 5.3 & 6 & 10.3 \\
\hline \multicolumn{5}{|l|}{ Having chronic Disease } \\
\hline Yes & 90 & 83.3 & 93 & 86 \\
\hline No & 18 & 16.7 & 15 & 14 \\
\hline \multicolumn{5}{|l|}{ Medical history of chronic diseases } \\
\hline \multicolumn{5}{|l|}{ \#Types of Chronic diseases } \\
\hline Diabetes Mellitus & 27 & 25.0 & 30 & 27.8 \\
\hline Hypertension & 20 & 18.5 & 23 & 21.3 \\
\hline Cardiac disease & 9 & 8.3 & 12 & 11.1 \\
\hline Respiratory disease & 7 & 6.5 & 9 & 8.3 \\
\hline Renal disease & 2 & 1.9 & 8 & 7.4 \\
\hline Arthritis & 20 & 18.5 & 25 & 23.1 \\
\hline Thyroid dysfunction & 1 & 0.9 & 7 & 6.5 \\
\hline Peptic ulcer & 5 & 4.6 & 11 & 10.2 \\
\hline Cholysystitis & 0 & 0.0 & 6 & 5.6 \\
\hline \multicolumn{5}{|l|}{ Drug history } \\
\hline \multicolumn{5}{|l|}{ Prescribed type of medication } \\
\hline Diabetes control medications & 27 & 25.0 & 30 & 27.8 \\
\hline Antihypertensive medications & 20 & 18.5 & 23 & 21.3 \\
\hline Cardiac medications & 9 & 8.3 & 12 & 11.1 \\
\hline Respiratory medications & 7 & 6.5 & 9 & 8.3 \\
\hline Renal medications & 2 & 1.9 & 8 & 7.4 \\
\hline Medications for arthritis & 20 & 18.5 & 25 & 23.1 \\
\hline Medications for thyroid dysfunction & 1 & 0.9 & 7 & 6.5 \\
\hline Medications for peptic ulcer & 5 & 4.6 & 11 & 10.2 \\
\hline Medications for cholysystitis & 0 & 0.0 & 6 & 5.6 \\
\hline
\end{tabular}


Table (3): Distribution of CHC patients (study and control groups) according to their medical history $(\mathrm{N}=216)$

\begin{tabular}{|c|c|c|c|c|}
\hline \multirow[t]{2}{*}{ Medical history of $\mathrm{HCV}$} & \multicolumn{2}{|c|}{$\begin{array}{l}\text { Study group } \\
(n=108)\end{array}$} & \multicolumn{2}{|c|}{$\begin{array}{c}\text { Control group } \\
(n=108)\end{array}$} \\
\hline & No. & $\%$ & No. & $\%$ \\
\hline \multicolumn{5}{|l|}{ Detection onset of disease } \\
\hline Complaining of symptoms & 42 & 38.9 & 42 & 38.9 \\
\hline Routine investigation at work & 1 & 0.9 & 1 & 0.9 \\
\hline Accidental & 65 & 60.2 & 65 & 60.2 \\
\hline \multicolumn{5}{|c|}{ Detection of disease through the following symptoms } \\
\hline Weight loss & 44 & 40.7 & 56 & 51.9 \\
\hline Fatigue & 48 & 44.4 & 59 & 54.6 \\
\hline Epistaxis & 15 & 13.9 & 25 & 23.1 \\
\hline Arthralgia & 50 & 46.3 & 60 & 55.6 \\
\hline Diarrhea & 5 & 4.6 & 18 & 16.7 \\
\hline Abdominal cramp & 27 & 25.0 & 38 & 35.2 \\
\hline Edema of limbs & 6 & 5.6 & 19 & 17.6 \\
\hline Fever & 20 & 18.5 & 33 & 30.6 \\
\hline Nausea and vomiting & 37 & 34.3 & 46 & 42.6 \\
\hline Loss of appetite & 58 & 53.7 & 68 & 63.0 \\
\hline Constipation & 23 & 21.3 & 33 & 30.6 \\
\hline Jaundice & 25 & 23.1 & 37 & 34.3 \\
\hline \multicolumn{5}{|l|}{ Duration of disease (years) } \\
\hline 6 months & 42 & 38.9 & 36 & 33.3 \\
\hline $1-5$ years & 65 & 60.2 & 52 & 48.1 \\
\hline $6-10$ years & 1 & 0.9 & 20 & 18.5 \\
\hline \multicolumn{5}{|l|}{$\begin{array}{l}\text { Previous hospitalization due to } \\
\text { HCV }\end{array}$} \\
\hline Yes & 108 & 100.0 & 108 & 100.0 \\
\hline No & 0 & 0.0 & 0 & 0.0 \\
\hline \multicolumn{5}{|l|}{ Prescribed Drugs for $\mathrm{HCV}$} \\
\hline $\begin{array}{l}\text { Pegylated alpha interferon and } \\
\text { Ribavirin combination therapy }\end{array}$ & 108 & 100.0 & 108 & 100.0 \\
\hline
\end{tabular}

\#Categories are not mutually exclusive 
Table (4): Frequency distribution of the study and control groups according to total health behaviors (physical, psychological, social \& spiritual) $(\mathrm{N}=216)$

\begin{tabular}{|c|c|c|c|c|c|c|c|c|c|c|c|c|}
\hline \multicolumn{3}{|c|}{ 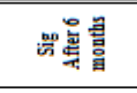 } & $\stackrel{9}{-}$ & & 要 & & 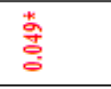 & & & 䓂 & & *⿳亠二口犬 \\
\hline \multicolumn{3}{|c|}{ 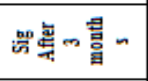 } & 䓂 & & 要 & & 容 & & & 言 & & 言 \\
\hline \multicolumn{3}{|c|}{ 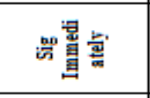 } & gे & & 䓂 & & $\stackrel{\circ}{-}$ & & & $\stackrel{9}{-}$ & & تี \\
\hline \multicolumn{3}{|c|}{ 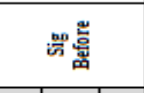 } & 䓂 & & 要 & & $\stackrel{\circ}{9}$ & & & $\stackrel{\circ}{-}$ & & $\begin{array}{l}\text { से } \\
\stackrel{*}{0} \\
0 \\
0\end{array}$ \\
\hline 淩 & હ & & 䓂 & & 䓂 & & $\stackrel{\circ}{-}$ & & & $\stackrel{\circ}{-}$ & & 总 \\
\hline \multirow{8}{*}{ 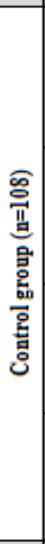 } & \multirow{2}{*}{ 总䜌 } & $\therefore$ & 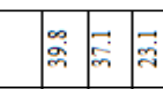 & & 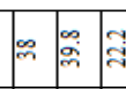 & & \begin{tabular}{|l|l|}
$\vec{b}$ & 0 \\
$\vec{b}$ & $\Xi$ \\
\end{tabular} & & 品 & $\because$ & 9 & 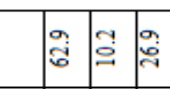 \\
\hline & & i & \begin{tabular}{l|l|l}
$\mp$ & 9 & $\approx$
\end{tabular} & & $F=$ & & 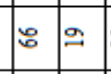 & & 要 & 0 & $\sim$ & $\because=2$ \\
\hline & & $\therefore$ & 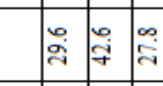 & & 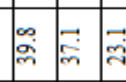 & & \begin{tabular}{|l|l|}
$\overrightarrow{0}$ & $\infty$ \\
$\infty$ & $\infty$
\end{tabular} & & $\overline{2}$ & $\approx$ & $\because$ & 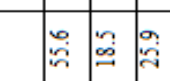 \\
\hline & & 2 & $\approx$ & & $\because$ क & & \begin{tabular}{|l|l|}
\multirow{i}{r}{} & $\vec{\pi}$ \\
\end{tabular} & & $\approx$ & + & $\circ$ & 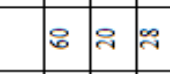 \\
\hline & & $\therefore$ & 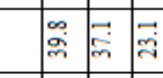 & & \begin{tabular}{|l|l|l}
$\infty$ & $\infty$ \\
& $\infty$ \\
\end{tabular} & & 8 & & مू & 9 & $\because$ & 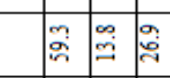 \\
\hline & & 完 & $=7$ & & $\Rightarrow=$ & & 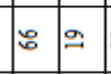 & & 8 & $\sim$ & 0 & $\begin{array}{lll} & \approx & 2\end{array}$ \\
\hline & \multirow{2}{*}{ 参 } & $\therefore$ & 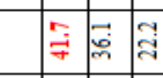 & & \begin{tabular}{|l|l|l}
$ळ$ & $\vec{m}$ & $\vec{m}$ \\
\end{tabular} & & \begin{tabular}{|l|l|} 
& $\overrightarrow{:}$ \\
$:$ & $\vec{\pi}$ \\
\end{tabular} & & $\infty$ & $\stackrel{4}{+\infty}$ & $\because$ & 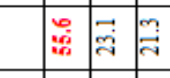 \\
\hline & & 8 & 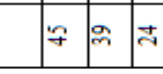 & & \begin{tabular}{|l|l|l} 
& 8 & 9 \\
\end{tabular} & & \begin{tabular}{|l|l|}
8 & ¿ \\
\end{tabular} & & 5 & $n$ & 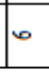 & 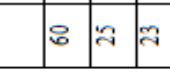 \\
\hline : & હ & & 蒡 & & 䓂 & & 晜 & & & 蔤 & & 䓂 \\
\hline \multirow{8}{*}{ 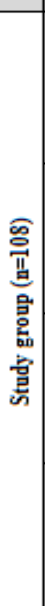 } & \multirow{2}{*}{. } & $\therefore$ & 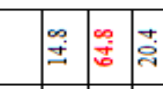 & & 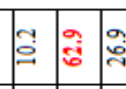 & & \begin{tabular}{l|l|} 
& $\square$ \\
& $a$ \\
\end{tabular} & \begin{tabular}{|l|} 
\\
\\
0
\end{tabular} & 2 & 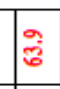 & 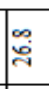 & 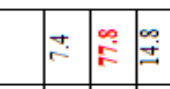 \\
\hline & & 完 & 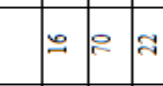 & & $\Rightarrow \approx 2$ & & 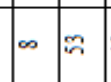 & o & 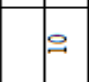 & 8 & 2 & \begin{tabular}{|l|l|l} 
& \pm & $\cong$
\end{tabular} \\
\hline & \multirow{3}{*}{ 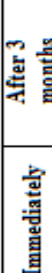 } & $\therefore$ & 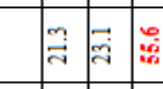 & & 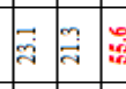 & & \begin{tabular}{|l|l|} 
& $\because$ \\
& $\sigma$ \\
\end{tabular} & i & 9 & 染 & 8 & 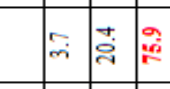 \\
\hline & & i & 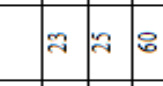 & & $\approx \approx-0$ & & \begin{tabular}{l|l|}
$\infty$ & $\infty$ \\
\end{tabular} & o & $\sim$ & $\infty$ & : & \begin{tabular}{|l|l|l} 
& $\approx$ & $\infty$ \\
\end{tabular} \\
\hline & & $\therefore$ & $\exists \stackrel{\Xi}{\Xi}$ & & $\because$ & & \begin{tabular}{|l|l|}
$\vec{n}$ & $m$ \\
\end{tabular} & 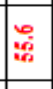 & $\infty$ & जे & $\frac{3}{2}$ & $\stackrel{\cong}{\cong}$ \\
\hline & 息 & 安 & $\approx a=$ & & $\therefore \approx F$ & & $\approx \approx$ & 8 & $\alpha$ & $\approx$ & $E$ & $\approx \approx:$ \\
\hline & \multirow{2}{*}{ 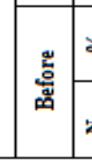 } & $\therefore$ & 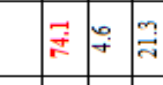 & & $\approx=$ & & \begin{tabular}{l|l|}
\multirow{G}{*}{} & $\stackrel{0}{\leftrightarrows}$ \\
\end{tabular} & $\overrightarrow{2}$ & $\begin{array}{ll} \\
\\
0\end{array}$ & 蒿 & $\begin{array}{l}\infty \\
\\
\end{array}$ & \begin{tabular}{|l|l|l}
\multirow{2}{*}{} & $\varrho$ & $\Xi$ \\
\hdashline
\end{tabular} \\
\hline & & 㝏 & $\approx \approx$ & & $\therefore \equiv \infty$ & & $\because 0$ & $\approx$ & 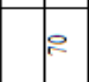 & $\approx$ & $\cong$ & 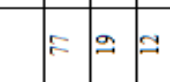 \\
\hline \multicolumn{3}{|c|}{ 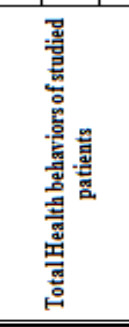 } & 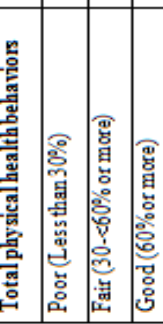 & 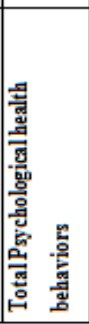 & 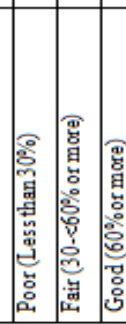 & 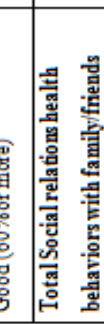 & 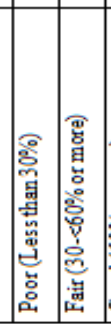 & 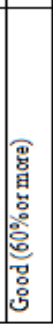 & 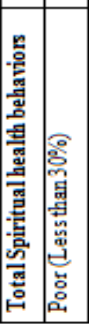 & \multicolumn{2}{|c|}{ 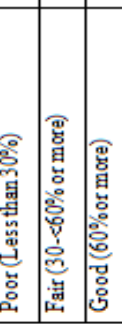 } & 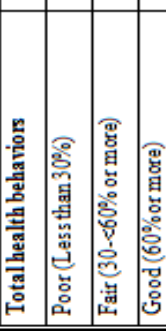 \\
\hline
\end{tabular}


Table (5): Correlation between total health behaviors related HCV and sociodemographic characteristics among the study and control groups $(N=216)$

\begin{tabular}{|l|c|c|c|c||}
\hline \multirow{2}{*}{\multicolumn{1}{c}{$\begin{array}{c}\text { Socio-demographic } \\
\text { characteristics }\end{array}$}} & \multicolumn{3}{c||}{ Total Health behavior } \\
\cline { 2 - 5 } Gender & r & P & r & P \\
\cline { 2 - 5 } & & & & \\
\hline Male & 0.012 & 0.905 & -0.141 & 0.144 \\
\hline Female & 0.65 & $0.05^{*}$ & 0.012 & 0.905 \\
\hline Age (years) & -0.88 & $0.0001^{*}$ & 0.063 & 0.52 \\
\hline Educational level & 0.75 & $0.001^{*}$ & 0.082 & 0.401 \\
\hline Marital status & & & & \\
\hline Married & 0.48 & $0.005^{*}$ & 0.148 & 0.127 \\
\hline not married & 0.012 & 0.915 & 0.148 & 0.127 \\
\hline Residence & & & & \\
\hline Rural & -0.77 & $0.001^{*}$ & -0.048 & 0.62 \\
\hline Urban & 0.012 & 0.905 & 0.012 & 0.905 \\
\hline Occupation & & & & \\
\hline Employed & 0.012 & 0.905 & 0.063 & 0.52 \\
\hline not employed & 0.012 & 0.905 & 0.063 & 0.52 \\
\hline \hline
\end{tabular}

\begin{tabular}{|lc|l|}
\hline Level of significant & $\begin{array}{l}\text { r: Spearman Rho correlation } \\
\text { coefficient }\end{array}$ \\
\hline Non significant (NS) & $\mathrm{P}>0.05$ & 0.00 to 0.24 weak or no correlation \\
\hline Significant (S) & $\mathrm{P} \leq 0.05$ & 0.25 to 0.49 fair correlation \\
\hline Highly significant (HS) & $\mathrm{P}<0.001$ & 0.50 to 0.74 moderate correlation \\
\hline Extremely high & $\mathrm{P}<0.0001$ & $0.75+$ strong correlation \\
\hline
\end{tabular}

\section{DISCUSSION:}

Hepatitis virus $\mathrm{C}$ infection is now a major health problem both in developed and developing countries. It is the most common cause of chronic liver disease, and cirrhosis all over the world (Kamal \& Nasser, 2008). Egypt is one of the highest prevalence Country of HCV in the world. Ten to twenty percent of the general population is infected and HCV is the leading cause of hepatocellular carcinoma and 
chronic liver disease (Doss et al., 2012). Furthermore, (WHO, 2013) reported that; $\mathrm{HCV}$ cause an inflammatory reaction that is localized within the liver, allowing the virus to gradually infect and destroy liver tissue.

HCV patients need information about their illness and its care, side effects of medications and health related behaviors. This could assist them to cope or live with HCV disease without complications and without transmitting HCV to others ( Stoove \& Mitchell, 2010 ; Quine ,2012). Therefore; this study is aimed to evaluate the effect of an educational program on chronic viral hepatitis $\mathrm{C}$ patients' knowledge related to hepatitis $\mathrm{C}$ virus disease treated by pegylated alpha interferon and ribavirin combination therapy.

As regard to gender the findings of the present study represented that more than half of the participated patients in both groups were males. This might be related to that males are more exposed to many factors than females, such as daily shaving with shared razors, unsafe sexual practices, abuse of alcohol or drugs. This result is in the same line with Abd-Elrasol (2011) who found that most of the studied patients were males. This finding is also supported by $\boldsymbol{C D C}$ (2015) which mentioned that $\mathrm{HCV}$ affect males than females. On the other hand, contradicting to this result. Abo-Elmatay(2014) found that females constituted half of the study and control group as well . Regarding age, the present study findings revealed that more than one quarter of the study and control groups were among the age group 30 to 40 years. This might be related to many factors among them; visiting dentistry clinics, beauty centers, barbers and tattooing as well as unsafe sexual behaviors that may increase the risk of hepatitis $\mathrm{C}$ infection. Moreover, the blood donors are the highest at that age group with a reason of getting money.

This result is in agreement with National institutes of health (2012) which reported that, many $\mathrm{HCV}$ infected persons are in the age group of 30 to 39 and who may become affected by complications of the disease over the following years. The International Conference on Emerging Infectious Disease (2012) added that there is an increased incidence of hepatitis $\mathrm{C}$ infections in people 15 to 34 years of age. This result is in contrast to Roberts (2010) who mentioned that, liver disease affects men, women, and children regardless of age, nationality, lifestyle or economic circumstances. 
Concerning education level, the results of the present study showed that approximately half of participated patients were uneducated. This might be related to the study setting which is a governmental non paid health care clinic that receive poor patients who are not covered with health insurance so, this setting offer health care to patients who are most probably non educated. Being not educated might have played a role in getting such infection as the higher the educational level the higher the awareness to the health care aspects including transmission of infection as well as health related behaviors. This result is in congruent with Demographic and Health Survey EDHS (2014) which reported that individual's with poor education were markedly more likely to be infected with HCV infection than more highly educated population. This is supported by Rajesh,(2012) who reported that, the prevalence of HCV was more in illiterate subjects.

In relation to the marital status, results of the present study clarified that most of study group and about half of control group were married. It may be due to our social and Arabic cultural issues related to early marriage at that age group. The higher infection rate between married might be related to many variables such as unawareness of infection with $\mathrm{HCV}$, or the partner is denying that the partner is infected or may be un confrontation to the partner, moreover sharing of personnel utilities may be some of the factors.

This is in agreement with Mohamed et al.(2010) who reported that marriage is a risk factor for HCV sero-positively. In the same point Abo-Elmatay (2014) stated that, the relationship between $\mathrm{HCV}$ infection and marriage provided evidence for sexual transmission of HCV. Their data suggest that this is somewhat rare. In addition potential sexual transmission, married couples share many exposures that could be risks for $\mathrm{HCV}$ transmission, both for transmission from one to the other, as well as transmission from a common source.

Concerning residence, the finding of the present study showed that the highest percentage of the participated patients were among those from urban areas, it could be explained that the study was conducted in Port Said city which is an urban area. The result of the present study was in line with Abd El-Shahed(2008) who reported that most of sample was from urban areas. These findings disagree with Eissia(2010) who estimated that 8-10 millions of Egyptian people have serological evidence of HCV infection, with higher rate among residents of rural areas in lower and middle Egypt. 
As regards Family members, the finding of the present study founded that the highest percentage of the participated patients in both groups their family members ranged from 1 to 5 . This quietly socially accepted family number within Egyptian families. This finding in disagreement with Abo-Elmatay (2014) who found that family member ranged from 4 to 6 and living with their families related to poor housing condition, absence of good eating habits, absence of family planning, living in rural areas and inability to reach to health insurance systems; cost and side effect of the treatment; and lack of access to screening, care and treatment limit the use of these therapies for most persons living with HCV infection globally.

In relation to occupation, the finding of the present study revealed that about of half of both groups were had free work. This might be related to study setting as Port Said is a free zone, that most of the citizen are most employed. These results in harmony with Abo-Elmatay(2014) who illustrated that the majority of the female wheres participated patients were housewives.

In relation to family income, results of the present study showed that half of study group and three quarters of control group hadn't enough monthly income. This might be due to unstability of economic status all over the world. This finding is in congruent with Mohamed (2011) who reported that the majority of his subjects had monthly income less than 100 Egyptian pounds. However, Karyn(2013) mentioned that, rich countries prepare for a hepatitis $\mathrm{C}$ virus treatment revolution, people in low and middle income countries remain without access to information ,prevention tools, diagnostics, care and treatment. In contrast to El-Metwaly(2009) who found that the majority of the patients had sufficient income.

Regarding to patients' family past history of HCV, the findings of the present study showed that half of the participated patients in both groups had first degree relatives history of HCV, This finding may be due to lack of family member awareness about risk and route of disease transmission, and they have had direct contact with the patient. This finding is supported by Abd-El-Raouf (2012) who found that more than one fourth of the $\mathrm{HCV}$ patients had family history of hepatitis $\mathrm{C}$. This could be explained as HCV is infectious disease and may spread in patient's family due to direct contacts without universal health precautions.

As regards total health behaviors among participating patients, the results of the present study revealed that the highest percentage had poor health behaviors before program implementation. The worst area of health related behaviors among the study 
group was psychological health behavior, followed by physical related health behavior while in the control group; the worst area was spiritual, followed by social health behavior. All areas related to health behaviors remained poor among patients of the control group. The total health behaviors improved significantly three months following program implementation among the study group specifically the spiritual health related behavior.

On the other hand, physical, psychological as well as spiritual health behaviors improved significantly immediately, as well as three months following program implementation. These findings are in agreement with Stoller et al.,(2009) who reportedthat the lowest percentage of patients in their study followed health behaviors to prevent transmission of $\mathrm{HCV}$ to others.In contrast, Bachand(2013) mentioned that the majority of patients followed health behaviors were related to blood donation, condom use as well as wound care.

Finally, the findings of the present study supported the study hypotheses that patients of the study group who were exposed to an educational program on health related behaviors showed more compliance with healthy behaviors, and had lower complaints from side effect of pegylated alpha interferon and ribavirin combination therapy after program implementation than before program.

Education as an essential aspect for hepatitis $\mathrm{C}$ patients prevention and treatment its importance has been demonstrated in many studies, aimed to teach patient about healthy habits, side effect of the treatment, and prevent and control complication .In this sense, effective education about $\mathrm{HCV}$ as a chronic disease requires knowledge, skills, listening abilities, understanding and negotiation skills from multi-professional team .Information is a relatively cheap intervention that could and should be a part of a standard care (Poroch,2008).

So the role of nurse should be to teach those patients and families not only about what will happen, but regarding what they will see, feel, and hear, but it should be about assessment, management of symptoms, coordination of care, correction of wrong knowledge of $\mathrm{HCV}$, providing emotional support, side effect of the treatment, complication of the disease, and follow -up care (Mossman et al., 2014). 


\section{CONCLUSION:}

Based on the findings of the present study, it can be concluded that:

the present study, it can be concluded that implementation of the health educational program enhanced patients' coping with $\mathrm{HCV}$ disease through modification of unhealthy behaviors.

\section{RECOMMENDATIONS:}

The study recommended the following

1- A colored booklet containing relevant information and simple figures about healthy behaviors of $\mathrm{HCV}$ patients should be available in all interferon units and be given to all newly admitted patients.

2- Mass media should provide to public and patients brief scientific information about HCV disease, its treatment and healthy behaviors toward HCV infection.

\section{REFERENCES:}

Abd-Elrasool Z. (2011): Effectiveness of the implementation of a health education program on the quality of life of patients with chronic Hepatitis C virus. Egypt: Unpublished Doctorate Thesis, Faculty of Nursing, Alexandria University; P.p. $69-73$.

Abd El-Shahed BA. (2008): Factors affecting quality of life of patients with liver cirrhosis. Unpublished master's thesis, in nursing science. Faculty of Nursing, Ain Shams University, Egypt.Abd-El-Raouf S. (2012): Effect of educational program for family have a member infected with $\mathrm{HCV}$, faculty of nursing, Mansoura University.

Abo-Elmatay P. (2014): Variability of hepatitis C virus. Hepatology, 28(2): 5780 5783

Bachand. (2013): Treatment of chronic hepatitis $C$ with interferon alfa-n3: A multicenter, randomized, open-label trial. Journal of herpetology, 25(2): The American Association for the study of liver diseases, 445.

CDC (2015) : incidence of Viral hepatitis C . US department of health and human services. Avilable at: file:///C:/Users/pc/Downloads/Documents/hcv-epidemiology-united-states.pdf.

CDC (2015) : incidence of Viral hepatitis C . US department of health and human services. Avilable at :file:///C:/Users/pc/Downloads/Documents/hcv-epidemiology-united-states.pdf 
Demographic and Health Survey EDHS. (2014): "Hepatitis C VIruS proteins". World J. Gastroenterol. 13 (17): 2406-15. PMID 17552023.

Doss F., Brown R. and Kwo P. (2012): Peginterferon alfa-2b and ribavirin for hepatitis $\mathrm{C}$ recurrence post-orthotopic liver transplantation (OLT): Final results from the Protect.

Eissia A. (2010): Transmission of HCV by organ transplantation. N Engl J Med, 326: $410-1$.

El-Berdan A. (2013):Assessment of health related behaviors among patients with viral hepatitis C . published thesis, Port- Said un.,Fac.,Ng.,M.Sc.,160, 64-72

El-Metwaly. (2009): The role of parental antischistosomal therapy in the spread of hepatitis C virus in Egypt. Lancet, mar 11, 355(9207): 887 - 91.

Foster G, Goldin R, Thomas $\boldsymbol{H}$ (2011): Chronic hepatitis C virus infection causes a significant reduction in quality of life in the absence of cirrhosis. Hepatology; 27(1):209-12.

Higher national institute of public health (2012): Hepatic steatosis in chronic hepatitis C virus infection: prevalence and clinical correlation. Gastroenterol Hepatol; 17(2):1808

International Conference on Emerging Infectious Diseases(ICEID) (2012): Hepatitis $\mathrm{C}$ Incidence Increasing in Younger people. Available at : http://www.medscape.com/viewarticle/760390.Accessed on 2/5/2013.

June M., Gortrude K., Jane E. and Susan M., (2011): Mosby's Clinical Nursing, (4th ed.) London: Mosby, pp.769, 770.

Kamal S. and Nasser E. (2008): Hepatitis C infection: A review on epidemiology and management of occupational exposure in health care workers for general physicians working in Iranian health network setting. Jundishapur journal of microbiology; 4(1): 1.

Karyn L. (2013): hepatitis C transmission prevention, and treatment knowledge among patients with HIV. Southern medical journal; 103(7): 635 - 41. 
McCoombs. (2010): Hepatitis C Virus (HCV) treatment uptake and changes in the prevalence of HCV genotypes in HIV/HCV -co infected patients. J Viral Hepat. Apr 27.

Mohamed H. (2011): Rehabilitation Program to Improve Quality Of Life for Patients Undergoing Renal Dialysis. Thesis for the Degree of Doctorate, Community and Environmental Health Nursing, Faculty of Nursing, Ain Shams University, P.95.

Mohamed M. (2010): Hepatitis C virus (HCV) infection in a community in the Nile Delta: population description and HCV prevalence. Hepatology, 32: 111-15.

Mossman S., Castet V., Pichard-Garcia L., Wychowki C., Meurs E. and Pascussi JM., et al. (2014): Serum derived HCV infection of primary human hepatocytes is tetraspanin CD81 dependent. J Virol 82: 569-574.

Poroch A. (2008): Effect of nursing management protocol III side effect of combination therapy, Faculty of Medicine, Menofia University, Egypt.

Rajesh S.(2012): Population Problem In Egypt As One of The Priority Health Problems In Tropical Areas. Zagazig Journal of Occupation Health and Safety 1(2), 87.

Roberts M. (2010): Hepatitis C virus (HCV) infection in a community in the Nile Delta: population description and HCV prevalence. Hepatology; 32: 111-15.

Stoller E., Webster N., Blixen C., Richard A., Perzynski A., Kanuch S. and DawsonN. (2009): Lay management of chronic disease: a qualitative study of living with hepatitis $C$ infection. American journal of health behavior; 33(4): 376 - 90.

Stoove S. and Mitchell O. (2012): Accuracy of rapid and point -of-care screening tests for hepatitis C: a systematic review and meta- analysis.Ann Intern Med; 157:558-77. 


\section{تأثير برنامـج تعليمى على السلوكيات المتعلقة بالصحة لمرضى الالتهاب الكبدى الوبائى

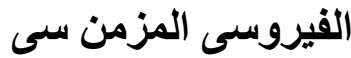

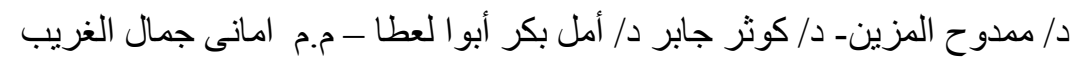

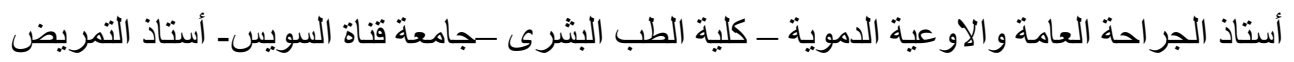
الباطني و الجر احيـ كلية التمريض- جامعة الاسكندريةـ مدرس التمريض الباطني و الجر احيـ كلية التمريض- جامعة بورسعيد- مدرس مساعد التمريض الباطني و الجر احيـ كلية التمريض- جامعة بورسعيد

\section{الخلاصة}

أجريت دراسة شبه تجريبيتهـف الى تقييمتأثير برنامج تعليمى على السلوكيات المتعلقة بالصحة لمرضى الالتهاب الكبدى الوبائى الفيروسى المزمن سى حيث إن الالتهابالكبديالوبائيالفيروسي سى يعتبر من أهم المشاكل الصحية فى بـ بـي

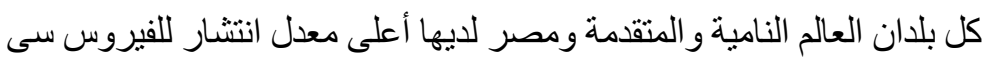
(15\%) وهو المسئول عن ما يقرب من (90\%) من حالات العدوى فى جميع أنحاء العالم والجدير بالذكر بأنه هو

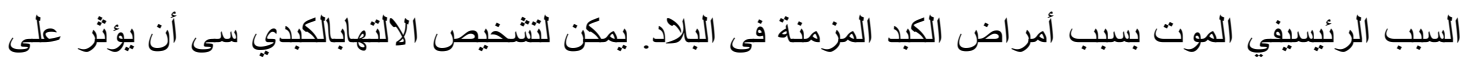

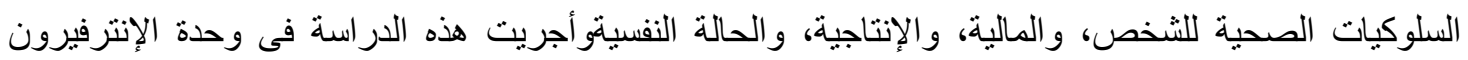
بمستشفى التضامن التابعة للتأمين الصحي ببورسعيد على 216 مريضا بفيروس سى ويعالجون بالإنترفيرونو انقسمت عينة البحث بالتساوى إلى مجمو عتين مجموعة الدراسة وتم تطبيق البرنامج عليها ومجموعة

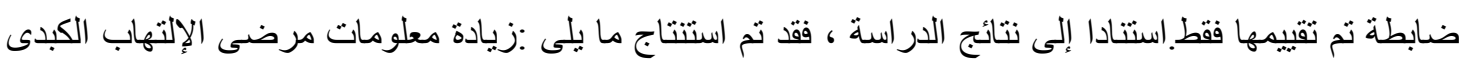
الوبائى الفيروسى المزمن سى عن مرضهم الذين شاركوا فى البرنامج التعليمى ، وان للبرنامج التعليمى الصحى :ألى

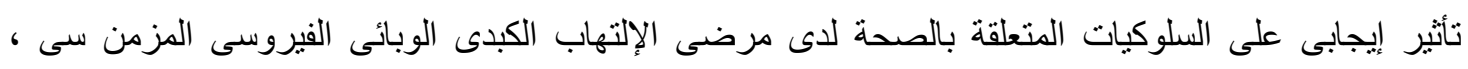
بالاضافة اللى قلة شكوى مرضى الإلتهاب الكبدى الوبائى الفيروسى المزمن سى الإلى الذين شاركوا فى البرنامج التعليممن الأعراض الجانبية التى يشتكون منها خلال فترة علاجهم بالعلاج المركب بيلاجيتد الفا إنترفيرون

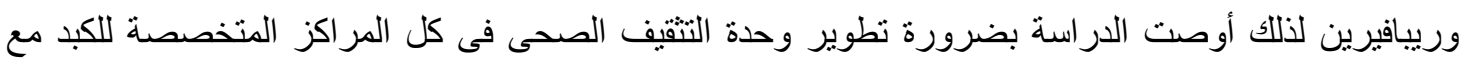
تو اجد تمريض مؤهل ومدرب طوال الوقت مع تنظيم جلسات منتظمة لتقديم المشورة لمرضى الالتهاب الكبدى المزمن سى وحل مشكلاتهم .

الكلمات الاسترشاديه : البرنامج التعليميـ السلوكيات الصحية ـ الالتهاب الكبدى الفيروسى سى 